\title{
Eco-restoration of a high-sulphur coal mine overburden dumping site in northeast India: A case study
}

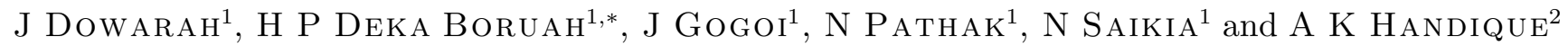 \\ ${ }^{1}$ Biotechnology Division, North-East Institute of Science 85 Technology, CSIR, Jorhat 785 006, Assam, India. \\ ${ }^{2}$ Biotechnology Department, Gauhati University, Guwahati 781 014, Assam, India. \\ *e-mail: dekaboruah@yahoo.com hpdekaboruah@yahoo.com
}

\begin{abstract}
Eco-restoration of mine overburden $(\mathrm{OB})$ or abandoned mine sites is a major environmental concern. In the present investigation, an integrated approach was used to rejuvenate a high-sulphur mine OB dumping site in the Tirap Collieries, Assam, India, which is situated in the Indo-Burma mega-biodiversity hotspot. A mine OB is devoid of true soil character with poor macro and micronutrient content and contains elevated concentrations of trace and heavy metals. Planting of herbs, shrubs, cover crops and tree species at close proximity leads to primary and secondary sere state succession within a period of 3 to 5 years. A variety of plant species were screened for potential use in restoration: herbs, including Sccharum spontaneum, Cymbopogon winterianus Jowitt (citronella), and Cymbopogon flexuosus (lemon grass) cover plants, including Mimosa strigillosa, M. striata, and M. pigra; shrubs, including Sesbania rostrata (dhaincha) and Cassia streata (cassia); and tree species, including Gmelina arborea (gomari) and Dalbergia sissoo (sissoo). Amendment with unmined soil and bio-organic matter was required for primary establishment of some plant species. Management of these plant species at the site will ensure long term sustainable eco-restoration of the coal mine-degraded land.
\end{abstract}

\section{Introduction}

The dumping of mine tailings and other reject materials (referred to as overburden, OB) generated from opencast coal or metal mines is considered as a major contributor to the ecological and environmental degradation (Cherfas 1992; Chaoji 2002; Ghose 2004; Deka Boruah et al 2008). OB materials are nutrient-poor, loosely adhered particles of shale, stones, boulders, cobbles, and so forth and are devoid of true soil character (Raju and Hassan 2003; Deka Boruah 2006; Gogoi et al 2007). Mine OB materials also contain elevated concentrations of trace metals. Consequently, ecological succession in a mine $\mathrm{OB}$ is a lengthy process. A minimum period of 50 years to a century is required to establish advanced specific plant species in denuded, mine OB-filled land; but this long time scales due to specific problems can be overcome by artificial interventions, that once identified, which are most successful if they use or mimic natural process (Dobson et al 1997).

Traditionally, mines are the sole mineral supply source, and exploration for coal is conducted without giving much regard to its serious impacts on the ecology and environment. Therefore, the coal mining industry is being placed under the red category, meaning it is in the top bracket of environmental degradation (Chaoji 2002), and coal mining is being considered for inclusion under the national superfund scheme. The chief environmental impacts due to mining are changes in soil stratification, reduced biotic diversity, and alteration of structure and functioning of ecosystems; these changes ultimately influence water and nutrient dynamics and trophic interactions (Matson et al 1997; Almas et al 2004; Ghose 2004).

Keywords. Mine overburden; environment degradation; ecology; eco-restoration; primary, secondary ecological succession. 
The remediation of soil that is heavily contaminated due to coal or metal mining involves excavation, removal of soil to secured land fields, and filling of top soil, which is expensive and requires site restoration. Alternatively, the contaminated soil may be dealt with bioremediation or phytoremediation, which is the use of plants or other biological measures to remove, destroy or sequester hazardous substances from the soil and waste piles (Salt et al 1995; Cunningham and Ow 1996; Ernst 1996). An account of specific plant species that have been used to combat different types of soil pollution has been given by Prasasd (2004). However, restoration of mine waste piles depends on the substrate characteristics and ability of the plant species to proliferate in the substratum.

In India, the amount of mine OB wasteland generated due to opencast coal mining is enormous. Presently, the north eastern coalfields of Coal India Limited (NECF-CIL), Margherita, Assam, have produced more than 1000 ha of mine OB wasteland. Reports are also available on the prospects and environmental issues related to the north east (NE) collieries (Akala 1995; Chaoji 2002). Due to the presence of high sulphur content $(2-12 \%)$, the mine OB of the NE collieries is highly acidic $(\mathrm{pH}$ 2.0-3.0) (Deka Boruah et al 2008). Consequently, ecological succession takes even longer.

Though there are many success stories of ecorestoration around the world (Cunningham and Berti 1993; Mendez and Maier 2008; Gonzalez and Gonzalez-Chavez 2006; Wong 2003), and in different parts of the country (Tiwary 2001; Pal 2003; Ghose 2004; Maiti 2007; Juwarkar and Jumbalkar 2008), to date no attempt is being made to remediate mine $\mathrm{OB}$ dumps in the NE region of India by utilising native plant species. This investigation sought to achieve eco-restoration of a high-sulphur containing coal mine $\mathrm{OB}$ dumping site through primary and secondary ecological succession of plants. Emphasis was given to the physico-chemical characteristics of the mine $\mathrm{OB}$ waste, planting methodology, amendment of organic matter and establishment of the plant species. The entire in situ experiment was conducted in the Tirap opencast coal mine overburden dumping site in Assam.

\section{Materials and methods}

\subsection{Description of the site and collection of soil samples}

Samples of tailings were collected from the site according to IS specifications (436-1953). A detailed description and visual characteristics of the site are described in figure 1, plate $1 \mathrm{~A}$ and $\mathrm{B}$.

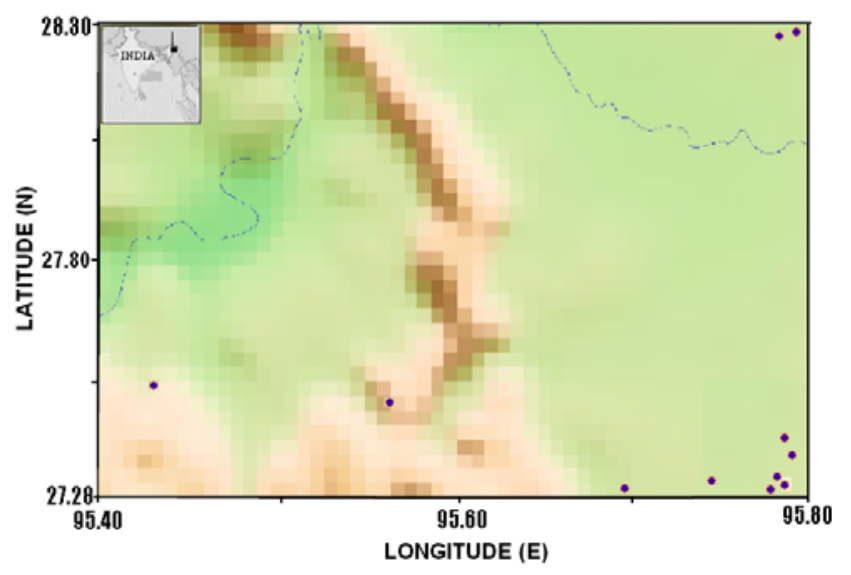

Figure 1. Location map of the eco-restoration site drawn with the help of generic mapping tools. Open stars indicate the sampling point of mine OB.

At each sampling location, 10 to 15 cores of the top $8 \mathrm{~cm}$ of substrate were collected at random. Composite samples were prepared by thoroughly mixing these samples as per IS specifications, and the prepared bulk samples were stored at $4^{\circ} \mathrm{C}$. Biochemical analysis of the substrates was performed within seven days of sampling.

\subsection{Physico-chemical and biochemical characterisation}

The $\mathrm{pH}$ of $50 \%(\mathrm{w} / \mathrm{v})$ soil and OB materials was determined using an automatic glass electrode $\mathrm{pH}$ meter, Systronics, Model 8330. Total carbon content was determined by potassium dichromate oxidation, and total nitrogen content by Kjeldahl digestion. The particle size of mine tailings and shale was determined in air dried samples by sieve analysis. Since $99 \%$ of the uncontaminated soil is contained in the $<0.355 \mathrm{~mm}$ fraction, unmined soils were not subjected for sieve analysis. The percentage of the total content of silt, sand and clays were analysed for $<0.355 \mathrm{~mm}$ fractions by laser diffraction particle size analyser, CILAS 100, Switzerland.

For sieve analyses, the mine OB was thoroughly mixed as per IS specifications, and representative samples of $1 \mathrm{~kg}$ each were passed through different sieve sizes ranging from $>25 \mathrm{~mm}$ to $<0.355 \mathrm{~mm}$. The composition of silt, sand and clay was determined in the $0.355 \mathrm{~mm}$ size fractions by laser diffraction particle size analyser. To verify the maximum ability of the mine tailings to release finer particles, mine $\mathrm{OB}$ samples were also mixed with water $(1: 3=$ material:water; $40 \mathrm{rpm}, 3 \mathrm{~h})$ in a $5 \mathrm{~kg}$ pot mill. The liberation of finer particles such as clay and silt will give an idea of the extent of degradation that could result due to long-term weathering of these materials in this highly rainy region. 

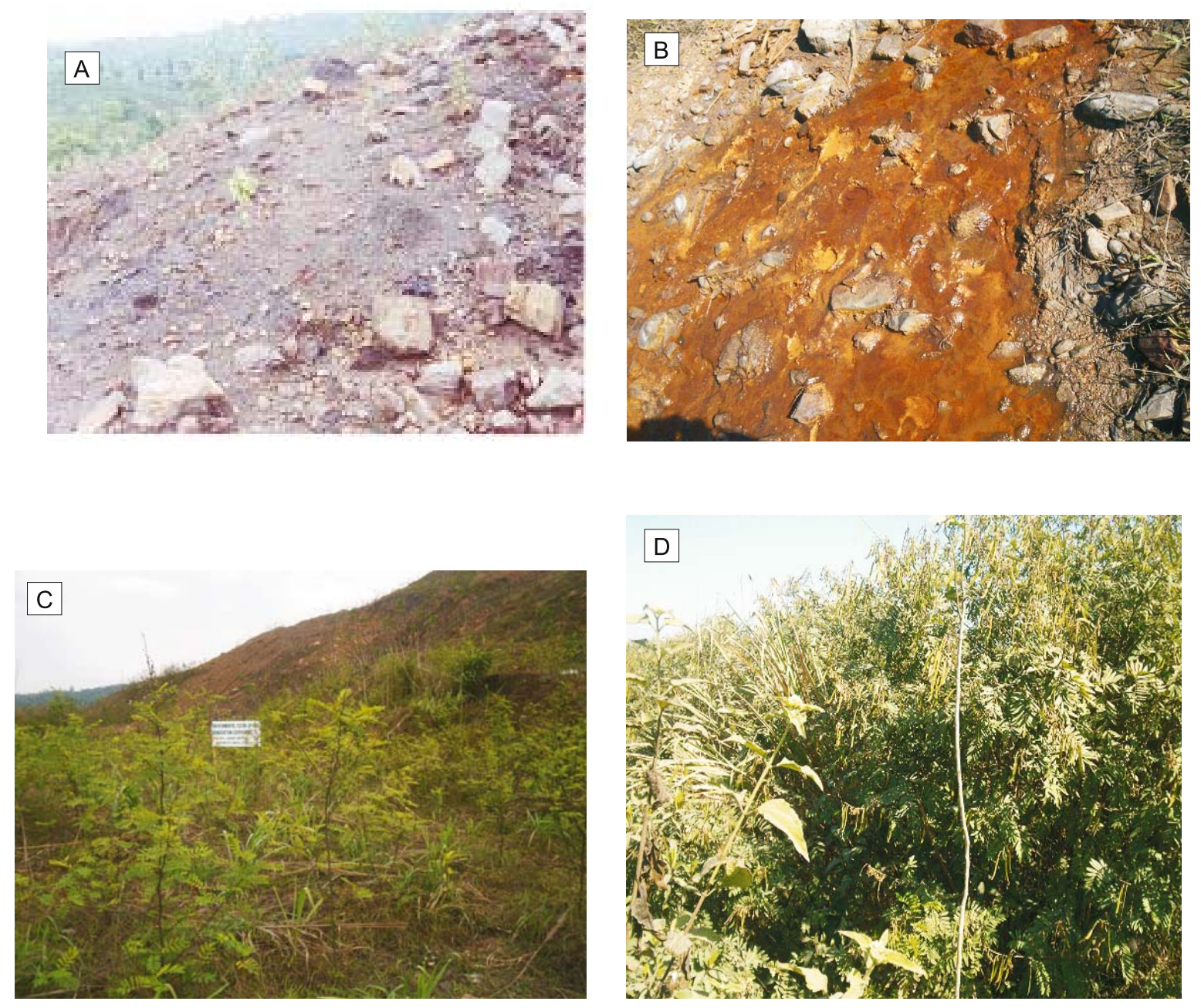

Plate 1. Mine OB dumping ground of Tirap opencast colliery, Assam, India. A, B = Before remediation of mine OB; $\mathbf{C}, \mathbf{D}=$ After remediation of mine OB dumping site.

Microbial biomass carbon was determined by the chloroform-fumigation method, using $0.5 \mathrm{M} \mathrm{K}_{2} \mathrm{SO}_{4}$ for extraction (Vance 2000). The organic C content was estimated by oxidation with potassium dichromate. The difference in $\mathrm{C}$ content between the fumigated and non-fumigated soil was converted to microbial biomass $\mathrm{C}$ (expressed in $\mathrm{mg} \mathrm{kg}^{-1}$ of oven dried soil) by applying a $\mathrm{KC}$ factor of 0.45 (Jenkinson 2004).

The serial dilution technique was used to determine the most probable number (MPN) of microorganisms as described by Alexander (1965). The presence of nitrogen fixing bacteria was determined using the medium developed by Bezbaruah et al (1995). Chemolithotrophic sulphur oxidisers present in coalmine tailings and unmined soil were grown using thiosulphate agar medium. For the enumeration of cellulose degraders, Skinner medium (1971) was used. Nutrient agar (Hi-media) was used to estimate the population density of heterotrophic bacteria. A colony counter was used to assess the total microbe count.
Phosphatase enzyme activity was determined by incubation at $37^{\circ} \mathrm{C}$ in phosphate buffer (pH 5.0) with $p$-nitrophenyl phosphate as the substrate. After $30 \mathrm{~min} \mathrm{CaCl}_{2}$ was added (to stop the reaction and to avoid coloration caused by organic and other matter), and the released $p$-nitrophenol was measured with a spectrophotometer at $570 \mathrm{~nm}$ (Tabatabai and Bremner 1969). $\beta$-glucosidase activity was determined as described for phosphatase activity except that the substrate was $p$-nitrophenyl- $\beta$-D-glucopyrenoside and the incubation time was $1 \mathrm{~h}$. Both phosphatase and $\beta$-glucosidase activities were quantified using a standard curve prepared from $p$ nitrophenol, and are expressed in p-nitrophenol released in $\mu \mathrm{mol} \mathrm{g}{ }^{-1} \mathrm{~h}^{-1}$. The dehydrogenase activity of the soil was determined according to Camina et al (1998) and quantified using an iodonitro tetrazolium formazon (INTF) calibration curve and expressed in $\mu \mathrm{mol} \mathrm{g} \mathrm{g}^{-1}$. The urease activity of the soil was determined according to Bezbaruah et al (1995), and the values 
Table 1. Vernacular plant species screened and their nature.

\begin{tabular}{|c|c|c|c|c|}
\hline Sl. no. & Name & Nature & Class & Family \\
\hline 1 & Bambosa & Herbs, perennial & Monocot & Poaceae \\
\hline 2 & Elephant grass & Herbs, perennial & Monocot & Poaceae \\
\hline 3 & Saccharum spontaneum & Herbs, perennial & Monocot & Poaceae \\
\hline 4 & Auxonopus & Herbs, perennial & Monocot & Poaceae \\
\hline 5 & Cymbopogon winterianus & Herbs, perennial & Monocot & Poaceae \\
\hline 6 & C. flexosus & Herbs, perennial & Monocot & Poaceae \\
\hline 7 & Commelina & Herbs, perennial & Monocot & Commelinaceae \\
\hline 8 & Cyperus & Herbs, perennial & Monocot & Cyperaceae \\
\hline 9 & Draecena & Herbs, perennial & Monocot & Dracenaceae \\
\hline 10 & Musa paradisiaca & $\begin{array}{l}\text { Rhizomatous, } \\
\text { monocarpic }\end{array}$ & Monocot & Musaceae \\
\hline 11 & Eclipta alba & Herbs, annual & Dicot & Asteraceae \\
\hline 12 & Ageratum & $\begin{array}{l}\text { Semi woody herbs, } \\
\text { annual }\end{array}$ & Dicot & Asteraceae \\
\hline 13 & Amaranthus & Annual herb & Dicot & Amaranthaceae \\
\hline 14 & Solanum sp & Herbs & Dicot & Solanaceae \\
\hline 15 & Ricinus communis & $\begin{array}{l}\text { Shrubs, annual to } \\
\text { perennial }\end{array}$ & Dicot & Euphorbiaceae \\
\hline 16 & Croton & Shrubs, perennial & Dicot & Euphorbiaceae \\
\hline 17 & Cassia streata & Shrubs, perennial & Dicot & Caesalpiniaceae \\
\hline 18 & Cassia fistula & Shrubs, perennial & Dicot & Caesalpiniaceae \\
\hline 19 & Caesalpania pulcherima & Tree, perennial & Dicot & Caesalpiniaceae \\
\hline 20 & Cassia coronj & Shrubs, perennial & Dicot & Caesalpiniaceae \\
\hline 21 & Sesbania rostrata & Lianes, annual & Dicot & Leguminosae \\
\hline \multirow[t]{4}{*}{22} & Mimosa pigra & Lianes, annual & Dicot & Fabaceae \\
\hline & M. pudica & Lianes, annual & Dicot & Fabaceae \\
\hline & M. strigillosa & Lianes, annual & Dicot & Fabaceae \\
\hline & M. streata & Tree, perennial & Dicot & Fabaceae \\
\hline 23 & Albizia lebbeck & Tree, perennial & Dicot & Fabaceae \\
\hline 22 & Dalbergia sisso & Lianes, annual & Dicot & Leguminosae \\
\hline 23 & Evolvulas & Tree, perennial & Dicot & Convolvulaceae \\
\hline 24 & Dipterocarpus & Tree, perennial & Dicot & Dipterocarpaceae \\
\hline 25 & Shorea robusta & Tree, perennial & Dicot & Dipterocarpaceae \\
\hline 26 & Tectona grandis & Tree, perennial & Dicot & Verbenaceae \\
\hline 27 & Gmelina arborea & Tree, perennial & Dicot & Verbenaceae \\
\hline 28 & Termenellia arjuna & Tree, perennial & Dicot & Combretaceae \\
\hline 29 & T. chebulla & Tree, perennial & Dicot & Combretaceae \\
\hline 30 & Mellia azadiracta & Tree, perennial & Dicot & Maliaceae \\
\hline 31 & Ficus bengalensis & Tree, perennial & Dicot & Maliaceae \\
\hline 32 & Delonix regia & Tree, perennial & Dicot & Fabaceae \\
\hline 33 & Eggle marmelos & Tree, perennial & Dicot & Rutaceae \\
\hline 34 & Michelia champaca Etc & Tree, perennial & Dicot & Magnoliaceae \\
\hline
\end{tabular}

All the plant species screened were vernacular plant and abundant in the neighbouring unmined site.

were expressed as $\mu \mathrm{mol} \mathrm{g}{ }^{-1} \mathrm{~h}^{-1}$ of thiocyanate released.

Total metal content associated in the composite material of mine $\mathrm{OB}$ and in the mine $<0.355 \mathrm{~mm}$ size fraction were analysed by atomic absorption spectrophotometer (AAS) and X-ray fluorescence spectrophotometry $(\mathrm{XRF})$. For this the composite materials and $<0.355 \mathrm{~mm}$ grain size was ground to $<200 \mathrm{~mm}$. It was then analysed by atomic absorption spectrophotometry (AAS) for the metals $\mathrm{Cd}, \mathrm{Co}, \mathrm{Cu}, \mathrm{Cr}$ and $\mathrm{Pb}$ in acid extract (Perkin Elmer Analyst 100) with the detection limit of $0.05 \mathrm{mg} \mathrm{L}^{-1}$ to $0.10 \mathrm{mg} \mathrm{l}^{-1}$ while $\mathrm{Hg}$ was determined in mercury hydride systems model MHS10. $\mathrm{Al}, \mathrm{Fe}, \mathrm{Ca}, \mathrm{Mn}$ and $\mathrm{S}$ were determined by X-ray fluorescence ED-XRF (P) photometer model, Xepos (Model: SPELLMANXRM 50P50X3385; S/N: 054811-1-1065). The instrument was calibrated by solid and liquid standard provided by spectro. Detection limits of the individual elements 


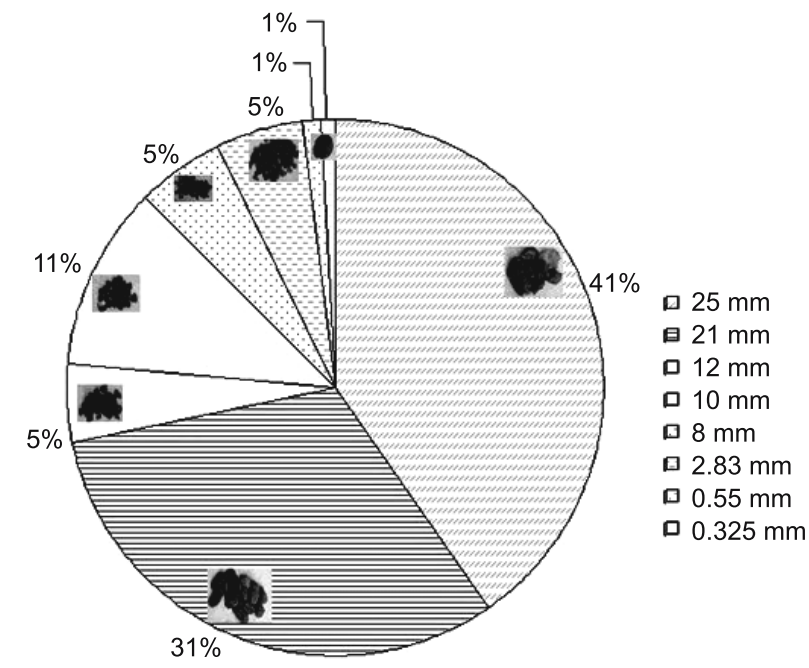

A

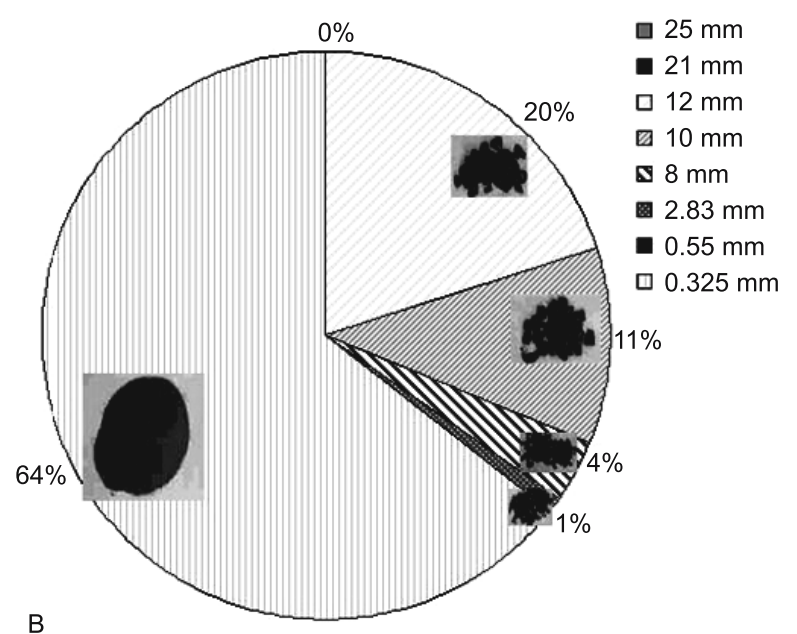

Figure 2. Grain size distribution of the overburden materials collected from Tirap collieries by sieve analysis.

ranged between 0.0003 and $0.15 \%$ for solid and between 1 and $100 \mathrm{ng} \mathrm{cm}^{2}$ in liquid samples. Pellets were prepared by mixing $4 \mathrm{~g}$ of powder with $0.9 \mathrm{~g}$ of Hoechst wax in a homogenizer (Swing Mill MM301) and then pressed in a manual hydraulic press with 10 tones.

\subsection{In situ eco-restoration}

A series of preliminary experiments were performed to screen the plant species for restoration suitability. Earthen pots with dimensions $14 \times 17 \times 24 \mathrm{~cm}$ were filled with mine OB. Lianes, shrubs and tree species were planted, and herbaceous species were included to create micro-climate conditions (table 1). The survival rate of plant species was recorded. Screened plant species were planted singly and alternately to achieve the primary and secondary sere state succession. Terracing was constructed in mine OB dumps for ecorestoration. In each terrace, a pit was prepared by amending with unmined soil and cowdung. Both line and fill methods were used to prepare the pits. Saplings grown without preparing the pit were considered controls. The ecological succession rate, i.e., population growth rate, diversity of plant species, vegetation structure, plant height, canopy size and ecological processes was recorded in the first and second year of restoration following standard ecological methods (Misrhra 1992).

\subsection{Growth rate over time}

The population growth rate for the study area was calculated according to the following formula (Mishra 1992): Population growth rate/new seedling/tiller generation $=\Delta N / \Delta t$ where $\Delta$ (delta) means change in $N=\left(N_{2}-N_{1}\right)$ the number of organisms, and change in time $=t\left(t_{2}-t_{1}\right)$. where $\Delta N n$ is production of new individuals in the population and specific mortality rate is expressed as $\%$ of initial population dying within a given time.

Measures of community structure, including density, frequency, abundance, relative dominance, and relative frequency of the restored sites were assessed by quadrate. The minimum size of the quadrate $(60 \times 60 \mathrm{~cm})$ was determined by the species area curve method (Sharma 1995).

\subsection{Statistics}

All the data were subjected to one way ANOVA analysis, and significant differences were calculated at $p<0.01$ and $p<0.05$.

\section{Results}

\subsection{Physico-chemical and biochemical characteristics}

The study site is situated between latitude $27^{\circ} 28^{\prime \prime}$ to $28^{\circ} 30^{\prime \prime}$ and longitude $94^{\circ} 40^{\prime \prime}$ to $95^{\circ} 80^{\prime \prime}$ in Assam, India, which is one of the locations of Indo-Burma mega-biodiversity (figure 1). The heaviest rainfall was recorded from May to October, and the maximum temperatures occurred from June to October (data not shown). Spot stratification observations of the mine OB dumping site showed no clearcut horizons. Sieve analysis confirmed that only $0.5 \%$ to $1.0 \%$ of the total mine $\mathrm{OB}$ was in the $<0.355 \mathrm{~mm}$ grain size fraction (figure 2A). Further, pot mill experiments confirmed that the mine OB metamorphoses immediately on coming in contact with water (figure $2 \mathrm{~B}$ ).

The $\mathrm{pH}$ of the mine $\mathrm{OB}$ was 2.5-3.0, and the $\mathrm{C}, \mathrm{N}$ and $\mathrm{P}$ contents were below the threshold limit (table 2). The mine $\mathrm{OB}$ was also found 


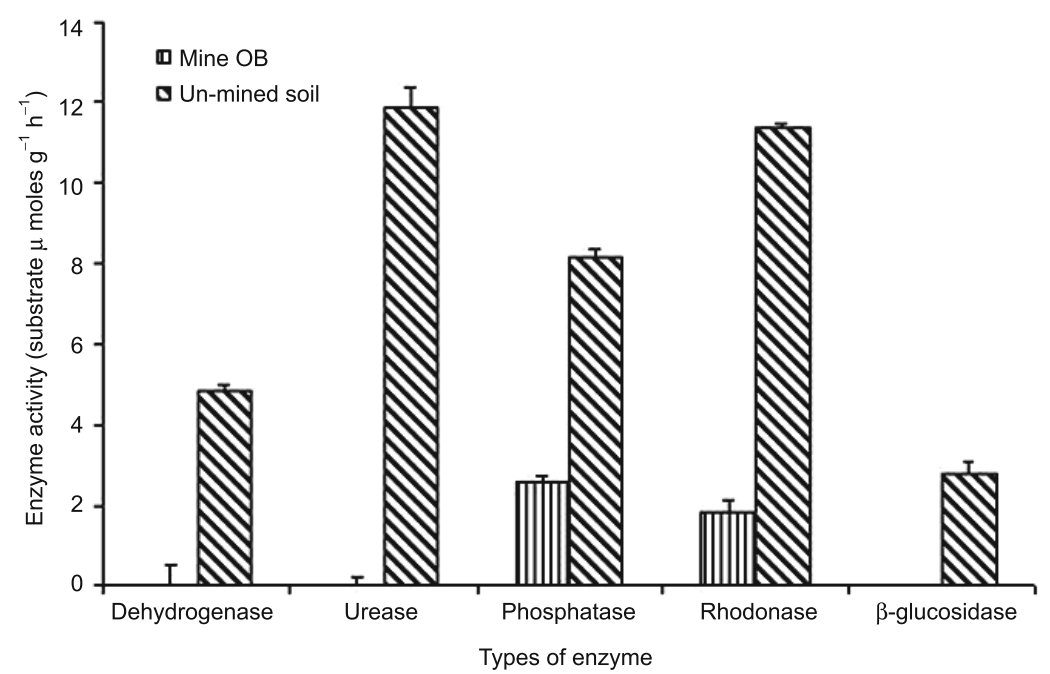

Figure 3. Comparison of microbial enzyme activity of the overburden materials in $<0.355$ mm size grain collected from Tirap collieries and unmined soil.

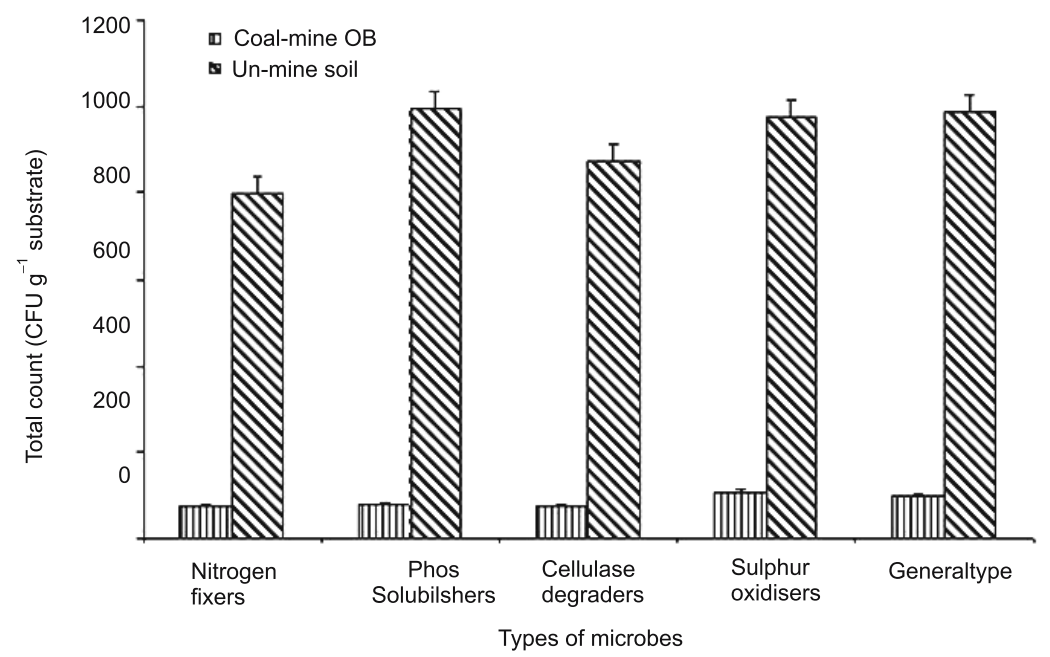

Figure 4. Comparison of total microbial count of the overburden materials in $<0.355 \mathrm{~mm}$ size grain collected from Tirap collieries and unmined soil.

to be of the sandy type, and the silt: sand: clay ratio was $39.9: 39.9: 21.9$. In addition, significantly less microbial biomass was found in coal mine OB $\left(64.33 \mathrm{mg} \mathrm{kg}^{-1}\right)$ compared to unmined soil (524 $\left.\mathrm{mg} \mathrm{kg}^{-1}\right)$. Similarly, significantly lower microbial MPN counts were found in mine OB (figure 5).

No $\beta$-glucosidase, dehydrogenase or urease activity was detected, and significantly less phosphatase and rhodanase activity was found in coal mine OB compared to unmined soil (figure 5). The enzyme activity of phosphatase and rhodanase was almost two times less than that of unmined soil.

A significantly higher amount of trace metals were detected in mine OB compared to unmined soil (table 3). In a composite sample of mine OB, Fe $(81.0 \%)$ was the most abundant trace metal, followed by $\mathrm{Al}(19.79 \%), \mathrm{S}$ (11.04\%), and $\mathrm{Mg}$
Table 2. Characteristics of mine $O B$ collected from Tirap colliery.

\begin{tabular}{lc}
\hline Constituents & Different constituents (\%) \\
\hline pH (50\% suspension) & $2.0-2.5$ \\
Clay & $21.93(2.2)$ \\
Silt & $38.13(2.2)$ \\
Sand & $39.94(2.26)$ \\
Carbon & 0.04 \\
Phosphorus & 0.005 \\
Nitrogen & 0.0001 \\
\hline
\end{tabular}

Data in parenthesis are the standard deviation of observed values.

(2.27\%); trace amounts of $\mathrm{Ca}$ and $\mathrm{Mn}$ were also detected. In the $<0.355 \mathrm{~mm}$ size grain fraction, Al $(20.14 \%)$ was most abundant, followed by Fe 


\section{$\square$ 1st year \\ $\boldsymbol{\nabla}$ 2nd year \\ (3rd year}

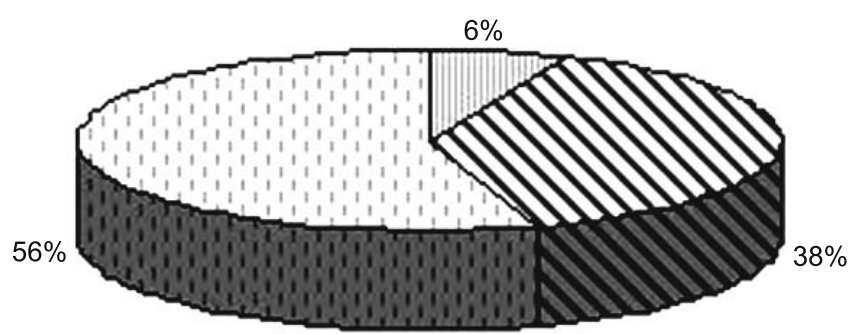

Figure 5. Population growth rate over the period of three years in the mine overburden eco-restoration site.

(13.21\%), S (12.51\%), and $\mathrm{Mg}(1.86 \%)$, with trace amounts of Ca and Mn.

Similarly, significantly higher concentrations of heavy metals were found in mine OB (table 4). The concentration of $\mathrm{Cr}$ (276.98 ppm) was highest, followed by $\mathrm{Pd}, \mathrm{Cu}, \mathrm{Co}$ and $\mathrm{Cd}$, while $\mathrm{Co}$ was not detected in unmined soil. Similar trends were observed for mine OB samples in the $<0.355 \mathrm{~mm}$ grain size fraction.

\subsection{In situ eco-restoration}

Amongst the tree species screened, gomari (Gmelina arborea) and sissoo (Dalbergia sissoo) belongs to the family verbenaceae and leguminosae, respectively had a mortality rate of $75 \%$, while the mortality of the other tree species belongs to the family caesalpiniaceae, dipterocarpaceae and also leguminosae were 90 to $100 \%$ (table 5). Two shrub species with the capability to fix atmospheric nitrogen, Cassia streata, a perennial, and Sesbania rostrata, an annual, shrubs belongs to the family caesalpiniaceae and leguminosae, respectively had a $75 \%$ mortality rate. In both cases, a pit was required for initial establishment. Amongst the cover crops screened, mimosa (M. pigra, M. striata and M. strigillosa) of the family fabaceae had a mortality rate of $80 \%$, while the other cover crops had $100 \%$ mortality. However, good survival rates were recorded in the grass species citronella (Cymbopogon winterianus Jowitt), lemon grass (Cymbopogon flexuosus), and Saccharum spontaneum, as well as in wild bamboo species belongs to the family poaceae. The germination (new seedling emergence) rates observed for citronella and lemon grass were $0.58 \%$ and $0.625 \%$, respectively, over the three-year study period. Germination rates of $45 \%$ and $21 \%$ were recorded for the shrub species Sesbania rostrata and Cassia streata, respectively. Over the period of observation, the cumulative population growth rate increased from $6 \%$ to $56 \%$ (figure 6). The plant species also reached an average height and canopy size of $40 \mathrm{~cm}$ to $>348 \mathrm{~cm}$ and 85 to $549 \mathrm{~cm}$, respectively (table 6 ).

\subsection{Plant vegetation structure}

After restoration was completed, the frequency distribution of plant density was recorded in each year (figure 7). The densities of herb species in the restored site were $43 \%$ and $55 \%$ in 2005 and 2006, respectively. Similarly, an incremental increase in plant density was observed for lianes (3\% to 10\%) and shrubs (12\% to $28 \%$ ) over the period of observation. On the other hand, a decreasing trend of plant density was seen in tree species (38\% to $8 \%$ ).

The characteristics of plant diversity recorded over the period of observation are described in table 7 , and ecological succession is shown in plate $1 \mathrm{C}$ and $\mathrm{D}$. A sequential progression of cryptograms, including bryophytes and pteridophytes, was found in the restored site. The natural growth of bryophytes was observed in over $50 \%$ of the area of the restored site, while the natural growth of pteridophytes was noted in less than $30 \%$ of the area. In addition, the distribution of herbs, shrubs and trees after the completion of the experiment was more than $50 \%$. After continuous monitoring for a period of three years, plant diversity indicative of secondary ecological succession was observed, including the progression from cryptograms to higher plants. This was achieved due to the introduction of coalmine OB resistant plant species in the restored sites in close proximity as well as successive refilling of the dead plants which makes the restored mine OB site suitable to grow lower plant and other invasive plant species.

Regarding vegetation structure in the restored sites, it was determined that 80 to $100 \%$ of the total area was covered with herbs, shrubs and tree species. In addition, for representative plant types $(80 \%)$ in the restored site, biomass ranged from 85 to $700 \mathrm{~cm}^{2}$, and the average height of the respective plant species ranged from $40 \mathrm{~cm}$ to $300 \mathrm{~cm}$. The overall ecological processes were assessed for increased soil organic matter which was in incremental order from beyond the detectable limit of $0.5 \%$ to $1.5 \%$ over the period of three years.

\section{Discussion}

Tirap OB dumps comprised of boulders, rejected coal, stones, and loosely adhered boulders, with varied colours such as white, yellow, and black. Sieve analysis found that only $0.5 \%$ of the particles 
Table 3. Availability of metal content in mine overburden collected from Tirap colliery and unmined soil.

\begin{tabular}{lcccccc}
\hline & \multicolumn{5}{c}{ Metal content (\%) } \\
\cline { 2 - 6 } Name of the soil & $\mathrm{Al}_{2} \mathrm{O}$ & $\mathrm{Fe}_{2} \mathrm{O}_{3}$ & $\mathrm{MgO}$ & $\mathrm{CaO}$ & $\mathrm{Mn}$ & $\mathrm{S}$ \\
\hline Unmined soil & 5.24 & 2.28 & 0.22 & 0.04 & 0.003 & 0.11 \\
& $(2.1)$ & $(0.6)$ & $(0.02)$ & & & $(0.01)$ \\
OB composite & 18.79 & 81.99 & 2.27 & 0.29 & 0.014 & 11.04 \\
& $(1.04)$ & $(3.23)$ & $(0.05)$ & $(0.1)$ & & $(2.03)$ \\
OB $<0.355 \mathrm{~mm}$ & 20.14 & 13.2 & 1.86 & 0.11 & 0.007 & 12.51 \\
& $(1.23)$ & $(1.51)$ & $(0.91)$ & $(0.07)$ & & $(6.03)$ \\
\hline
\end{tabular}

Data in parenthesis are the standard deviation of observed values.

Table 4. Availability of metal content in mine overburden collected from Tirap colliery and unmined soil.

\begin{tabular}{lccccccc}
\hline & & \multicolumn{5}{c}{ Metal content $(\mathrm{ppm})$} \\
\cline { 3 - 8 } Name of the soil & $\mathrm{Hg}(\mathrm{ppb})$ & $\mathrm{Mo}$ & $\mathrm{Pb}$ & $\mathrm{Cd}$ & $\mathrm{Co}$ & $\mathrm{Cu}$ & $\mathrm{Cr}$ \\
\hline Unmined soil & 0.03 & 0.04 & 21.8 & 3.17 & $\mathrm{BDL}$ & 25.77 & 150.67 \\
& & & $(2.3)$ & $(1.8)$ & & $(2.5)$ & $(2.7)$ \\
OB composite & 0.25 & 0.12 & 74.29 & 14.14 & 21.82 & 46.03 & 276.98 \\
& $(0.19)$ & $(0.05)$ & $(4.9)$ & $(2.5)$ & $(5.7)$ & $(2.6)$ & $(20.58)$ \\
OB $<0.355 \mathrm{~mm}$ & 0.03 & 0.12 & 50.53 & 6.28 & 35.33 & 72.6 & 312.1 \\
& $(0.01)$ & $(0.01)$ & $(6.46)$ & $(1.1)$ & $(8.3)$ & $(0.11)$ & $(15.44)$ \\
\hline
\end{tabular}

Data in parenthesis are the standard deviation of observed values.

Table 5. Mortality and new seedling/tiller emergence rate over the period of observation in mine overburden eco-restoration site of Tirap colliery.

\begin{tabular}{lccccc}
\hline Plant species & \multicolumn{2}{c}{ Mortality rate $(\%)$} & & \multicolumn{2}{c}{ New seedling/tiller emergence (\%) } \\
\cline { 2 - 3 } & 1st year & 2nd year & & 1st year & 2nd year \\
\hline Cymbopogon winterianus & 50 & 30 & & $1.58(0.22)$ & $0.42(0.22)$ \\
C. flexosus & 50 & 0 & & $0.41(0.21)$ & $0.45(0.20)$ \\
Bambosa wild type & 30 & 0 & & $0.25(0.12)$ & $0.62(0.21)$ \\
Bambosa jatibah & 100 & Nil & & & \\
Mimosa pigra & 80 & 0 & & $62.5(3.7)$ & $62.50(3.3)$ \\
M. strigillosa & 80 & 0 & & $60.12(3.8)$ & $60.12(3.8)$ \\
M. streata & 80 & 0 & & $62.38(5.3)$ & $62.38(3.7)$ \\
Sesbania rostrata & 75 & 0 & & $45.80(3.4)$ & \\
Cassia streata & 75 & 35 & & $20.83(3.3)$ & \\
C. coronj & 90 & 0 & & & \\
Caesalpaenia & 100 & 0 & & & \\
Siris & 99 & 0 & & & \\
Gmelina arborea & 75 & 0 & & & \\
Shorea robusta & 99 & 0 & & & \\
\hline
\end{tabular}

Plant species which showed survival after first year of planting were recorded. Data in parenthesis are the standard deviation of observed values.

in the OB dumps of Tirap collieries are in the $<0.355 \mathrm{~mm}$ grain size fraction and bears no true soil characters. The OB is highly acidic in nature ( $\mathrm{pH} 2.0$ or less) due to high amounts of elemental as well as pyretic sulphur. In general, the $\mathrm{Fe}(81.0 \%)$ and $\mathrm{S}(2$ to $12 \%)$ concentrations were high in the mine OB of the Tirap collieries.
The high concentration of $\mathrm{S}$ and the acidic $\mathrm{pH}$ in north-eastern $\mathrm{OB}$ dumps are unique in character. In addition, very low $\mathrm{C}, \mathrm{P}$ and $\mathrm{N}$ contents were recorded. The trace metal concentrations were significantly higher in the mine OB of the Tirap collieries compared to that of unmined soil. A high $\mathrm{S}$ and $\mathrm{Fe}$ content along with acidic mine $\mathrm{OB}$ of 
Table 6. Height and canopy size of some of the plant species of the mine overburden eco-restoration site of Tirap collieries after three years.

\begin{tabular}{lcc}
\hline Plant species & Height (inch) & $\begin{array}{c}\text { Canopy size } \\
\left(\mathrm{cm}^{2}\right)\end{array}$ \\
\hline C. flexosus & $132(1.15)$ & $200(2.0)$ \\
Bambosa wild type & $85(2.6)$ & $85(2.5)$ \\
Saccharum spontaneum & $302(21.1)$ & $183.17(30.3)$ \\
Mimosa & & $540.00(2.4)$ \\
Cassia streata & $259(4.9)$ & $283.04(2.1)$ \\
C. coronj & $40(3.6)$ & $85(1.5)$ \\
Dalbergia sisso & $348(5.0)$ & $245.91(12.0)$ \\
Gmelina arborea & $132(2.1)$ & $203.29(12.0)$ \\
\hline
\end{tabular}

Data in parenthesis are the standard deviation of observed values.

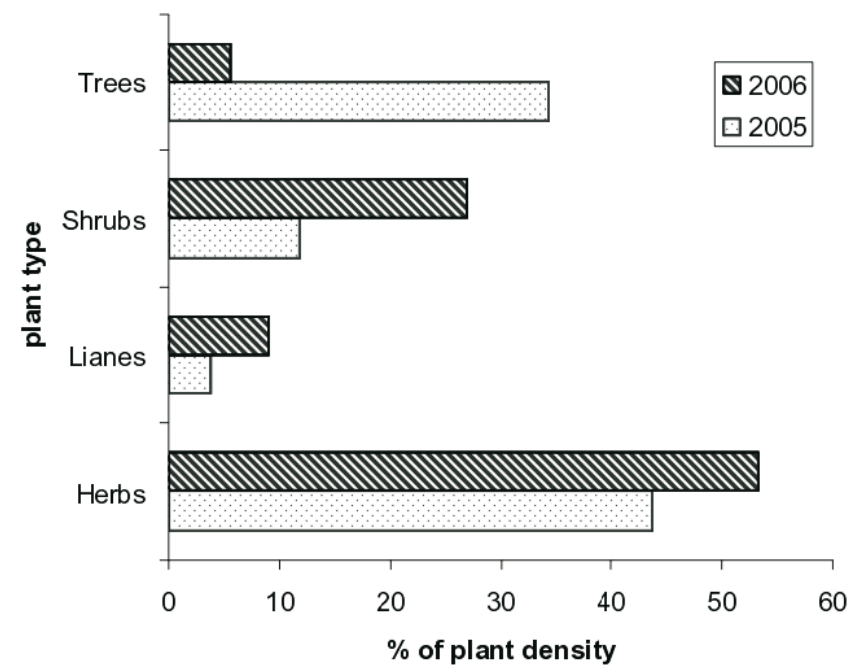

Figure 6. Frequency distribution of plant diversity in mine OB remediated site of Tirap collieries.

NE collieries were earlier reported by Akala (1995). Mine OB materials are devoid of true soil character, and contain boulders, cobbles, pebbles and other rejected mine materials were earlier reported by many workers (Cherfas 1992; Ford and Walker 2003; Juwarkar and Singh 2007; Kundu and Ghose 1994). Microbial population size and soil enzyme activity are considered to be good indicators of soil health (Anderson and Domsch 1990; Insam and Domsch 1988). Ghose (2004) described the effects of opencast mining on the fertility of soils. In the present investigation, very low microbial population size and enzyme activities were found in the mine OB dumping site of the Tirap collieries. No dehydrogenase, urease or $\beta$-glucosidase activities were detected in mine $\mathrm{OB}$, while a ten-fold lower phosphatase activity was seen in the mine OB compared to the unmined soil.

High acidity and above threshold limits of trace metals such as $\mathrm{Fe}, \mathrm{Al}, \mathrm{Cr}$ with no true soil behaviour are the major hindranges in eco-restoration of OB dumps of Tirap collieries. High acidity and above-threshold limit of trace metals retard the germination, inhibit root growth and also highly phytotoxic. Reports are available on the cause of plant death in mine OB stress due to no organic matter or macronutrients, without normal soil structure with high levels of autotrophic iron and sulphur oxidisers associated with plant death in eco-restoration of highly acidic mine OB (Schippers et al 2000; Mendez and Maier 2008). Dobson et al (1997) stated that such mine OB wastelands require a period of 100 years to colonise specific plant species.

To overcome the plant death in eco-restoration of mine OB of Tirap colliery, screening of plant species to thrive under mine OB stress conditions was performed in situ. The principle behind the use of native plant species is that these species should be tolerant to high-stress conditions (Cunningham and Ow 1996). Thirty-six different plant species were screened representing twenty different families belonging to the herbaceous, liane, shrub and tree groups. Amongst the herbaceous plant species, Axonopus, Saccharum spontaneum, and the economically important essential-oil bearing plants Cymbopogon winterianus Jowitt and C. flexuosus were found to be the most stress-tolerant. These plants were able to resist the stress conditions of mine OB due to the nature of their fibrous root systems. The liane species Mimosa pigra, M. streata, and M. strigillosa were also able to resist OB stress. However, in order to cultivate these species in mine $\mathrm{OB}$, acclimatisation of the plants in the in situ environment through preparation of an artificial pit was required. In addition, the shrub species Cassia streata and Sesbania rostrata and the tree species gomari (Gmelina arborea) and sissoo (Dalbergia sissoo) were determined to be resistant to mine OB stress in the Tirap colliery. The resistance of Gmelina arborea and Dalbergia sissoo to mine OB stress was also shown by the work of Juwarkar and Singh (2007) and Singh et al (1996). 


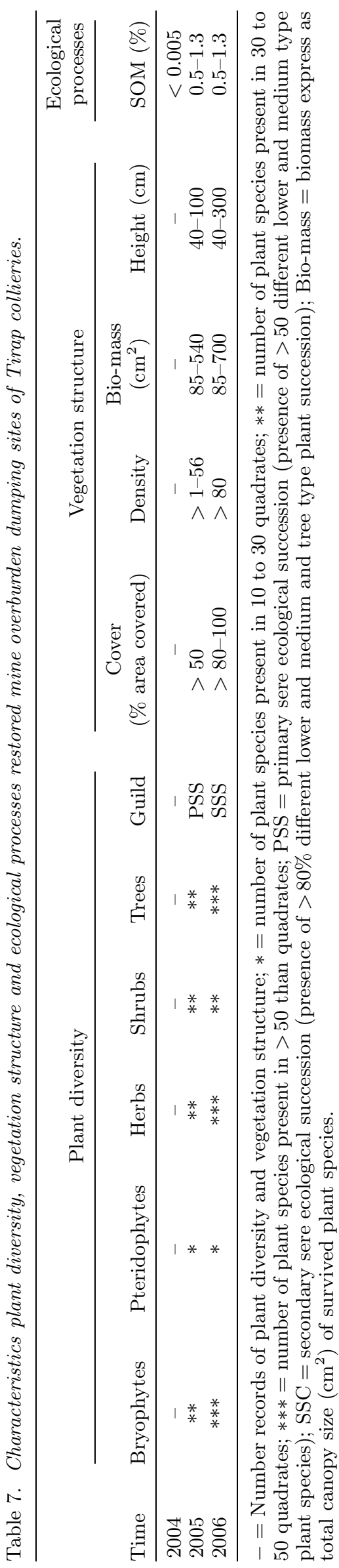

The goal behind the screening of herbs, lianes, shrubs and tree species was to achieve primary, secondary and tertiary ecological succession within a short period of time in an integrated approach. The herbs support creation of microclimatic conditions in the mine $\mathrm{OB}$ environment, and are able to proliferate by generating new tillers after establishment. Thereby, they can cover the exposed area rapidly. On the other hand, lianes (Mimosa pigra, M. streata, M. strigillosa) and shrubs (Sesbania rostrata and Cassia streata) are able to produce fruit within a year and thus increase their population size. This allows the plants to maintain their continuity across generations. In the present investigation, we found that the seedling growth rate was low, but sufficient to maintain the subsequent plant generations.

The outcome of eco-restoration depends on the nature of the plant distribution after restoration of the sites. Therefore, the record of ecological succession and processes is important to prove the success of eco-restoration (Eamus et al 2005). In addition, the general challenge of eco-restoration is in developing a site-specific strategy, as all sites around the world not alike (Hariis et al 2006). In the present investigation, an overall $8 \%$ to $50 \%$ frequency density of plant populations was found. The ecological succession measures studied were plant diversity, vegetation structure and ecological processes. The plant diversity results indicated the presence of cryptograms, bryophytes (Riccia, Marchantia, Anthoceros, and moss species), pteridophytes (Lycopodium, Selaginella, Pteris), herbs, shrubs and trees in the restored mine OB. Overall, a secondary sere ecological succession was observed in the restored mine $\mathrm{OB}$ site.

Regarding vegetation structure, 80 to $100 \%$ coverage was observed, the plant species density was more than $80 \%$, and biomass production was $700 \mathrm{~cm}^{2}$. The vegetation height in the restored site was determined by both understory and tree species. Soil organic matter is considered to be an indicator of total biomass production in restored sites; in the present investigation, ecological processes produced an appreciably enhanced soil organic matter accumulation, with concentrations increasing from 0.001-0.005\% to $0.5-1.3 \%$. A strategic change was adopted to achieve a quick succession of plant cover in exposed land within a period of one to three years. Therefore, simultaneous planting of different plant species using a filled pit preparation method to enhance plant survival and density was performed to achieve an ecological pyramid of primary, secondary and tertiary sere states of ecological succession. Dobson et al (1997) reported a similar strategic approach to achieve a climax state of succession within a short span of time. In the 
present investigation, a 100\% succession of primary and secondary ecological states was achieved by cultivating various plant species.

\section{Conclusion}

Lack of true soil characteristics, low biological activity, and acidic $\mathrm{pH}(2.0)$ were unique phenomena in a mine OB dumping site in NECFCIL, Margherita. Trace metal concentrations were also significantly higher in the mine OB environment compared to unmined soil. Under these adverse conditions, establishment of plant species takes a long period of time and ecological degradation is enormous. Planting of herbaceous monocots with fibrous root systems such as citronella, lemon grass, Saccharum spontaneum, lianes and shrub species accelerates the ecological processes in an adverse mine OB environment of Tirap colliery. The present investigation will be helpful in screening and simultaneous planting of various plant species to re-cover high sulphur containing mine OB-denuded land, leading to long term sustainable eco-restoration.

\section{Acknowledgements}

The authors are thankful to Dr P G Rao, Director, RRL, Jorhat for his support. The authors also thank CSIR, New Delhi for financial support and NEERI, Nagpur for co-ordinating the work. The authors are grateful to Dr B K Gogoi, Head, Biotechnology, and Dr S Baruah, Geoscience, for GMT. Authors are also thankful to the anonymous reviewer for his critical suggestions and comments in improving the manuscript.

\section{References}

Akala B 1995 North Eastern coalfields - some highlights; J. Mines, Metals and Fuels 43(9-10) 303-305.

Alexander M 1965 Most probable number methods for microbial population, In: Methods for soil analysis 2 (ed.) Black C A, Che. Micro. Pro. 1 462-472.

Almas A R, Bakken L R and Mulder J 2004 Changes in tolerance of soil microbial communities in $\mathrm{Zn}$ and $\mathrm{Cd}$ contaminated soils; Soil Biol. Bioch. 36 805-813.

Anderson J P E and Domsch K H 1990 Application of ecophysiologocal quotients ( $\mathrm{QCO}_{2}$ and Dissolved Oxygen) on microbial biomass from soil of different cropping histories; Soil Biol. Bioche. 25 393-395.

Bezbarua B, Saikia N and Bora T 1995 Effect of pesticides on most probable number of soil microbes from tea (Camellia sinensis) plantation and uncultivated land enumerated in enrichment media; Ind. J. Agr. Sci. 65(8) 578-583.

Camina F, Trasar-Cepeda C, Gil-Sotres F and Leiros M C 1998 Measuring of dehydrogenase activity in acid soils rich in organic matter; Soil Biol. Bioche. 30 1005-1011.
Chaoji V 2002 Environmental challenges and the future of Indian coal; J. Mines, Metals and Fuels 11 257-262.

Cherfas J 1992 Trees help nature reclaim the slag heaps; New Sci. 14-15 24-29.

Cunningham S D and Berti W R 1993 The remediation of contaminated soils with green plants: An overview; In: Vitro Cell. Deve. Biol., J. Tissue Cult. Assoc. 29 207-212.

Cunningham S D and Ow D W 1996 Promises and prospects for phytoremediation; Plant Phys. 110 715-719.

Deka Boruah H P 2006 North eastern coal and environment: An overview. Proc. on Characterization and Gainful Utilisation of NE Coal, Published by RRL, Jorhat, pp 28-33.

Deka Boruah H P, Rabha B K, Pathak N and Gogoi J 2008 Non-uniform patchy stomatal closure of a plant is a strong determinant of plant growth under stressful situation; Curr. Sci. 94 1310-1314.

Dobson A P, Bradshow A D and Baker A J M 1997 Hopes for the future: restoration ecology and conservation biology; Sci. 277 515-522.

Eamus D, Macinnis-Ng C M O, Hose G C, Zeppel M J B, Taylor D T and Murray B R 2005 Ecosystem services: An ecophysiological examination; Aust. J. Bot. 53 1-19.

Ernst W H O 1996 Availability of heavy metals and decontamination of soils by plants; App. Geol. J. Int. 11163.

Ford K L and Walker M 2003 Abandoned mine waste repositories: sites selection, design and cost, Technical Note 410, Denver Bureau of Land Management.

Ghose M K 2004 Effect of opencast mining on soil fertility; J. Sci. Indust. Res. 63 1006-1009.

Gogoi J, Pathak N, Dowrah J and Deka Boruah H P 2007 In situ selection of tree species in environmental restoration of opencast coalmine wasteland; Proceedings of Int. Sem. on MPT 2007, Allied Publisher, pp 678-681.

Gonzalez R C and Gonzalez-Chavez M C A 2006 Metal accumulation in wild plants surrounding mining wastes: Soil and sediment remediation (SSR); Environ. Poll. 144 $84-92$.

Hariis J A, Hobbs R J, Higgs E and Aronson J 2006 Ecological restoration and global climate change; Rest. Ecol. 14 170-176.

Insam H and Domsch K H 1988 Relationship between soil organic carbon and microbial biomass on chronosequences of reclamation sites; Microb. Ecol. 15 177-188.

Jenkinson D, Brookes C P and Powlson D S 2004 Measuring soil microbial biomass; Soil Biol. Bioche. 36 5-7.

Juwarkar A A and Singh S K 2007 Utilisation of municipal solid waste as an amendment for reclamation of coal mine waste dump; Int. J. Environ. Tech. Manag. 7(3/4) $407-420$

Juwarkar A A and Jumbalkar H P 2008 Phytoremediation of coal mine spoil dump through integrated biotechnological approach; Biores. Technol. 99 4732-4741.

Kundu N K and Ghose M K 1994 Impact on soil quality due to opencast coal projects; In: Proceeding Second National Seminar on Minerals and Ecology. (ed.) Banerjee S P, Indian Schools of Mines, Dhanbad, Oxford and IBH Publishing, New Delhi.

Maiti S K 2007 Bioremediation of coalmine overburden dumps with special emphasis in micronutrients and heavy metals accumulation in tree species; Environ. Monit. Assess. 125 111-122.

Matson P A, Parton W J, Powere A G and Swift M J 1997 Agricultural intensification and Ecosystem properties; Sci. 277 504-509.

Mendez M O and Maier R M 2008 Phytostabilization of mine tailings in arid and semiarid environments An emerging remediation technology; Environ. Health Prospect. 116 278-283. 
Mishra K C 1992 Manual of Plant Ecology; Oxford IBH Publishing Co. Pvt. Ltd.

Pal B K 2003 Health and safety risk assessment in environmental management of mining operations; J. Mines, Metals and Fuels 51(7-8) 245-250.

Prasad M N V 2004 Phytoremadiation of metals in the environment for sustainable development; Proc. Nat. Acad. Sci. India 70 71-98.

Raju K S and Hassan M 2003 Role of Indian Bureau of Mines in protection of environment in the minerals sector; J. Mines, Metals and Fuels 51(6) 196-200.

Salt D E, Blaylock M, Kumar P B A N, Dushenkov V, Enseley D D, Chet I and Raskin I 1995 Phytoremediation: A novel strategy for removal of toxic metals from the environment using plants; Biotechnol. 13 468-474.

Schippers A, Jozsa P G, Sand W, Kovacs Z M and Jelea M 2000 Microbiological pyrite oxidation in a mine tailings heap and its relevance to the death of vegetation; Geomicrobiol. J. 17 151-162.
Sharma P D 1995 Ecology and Environment, Rastogi Publication, Meerut, India.

Singh R S, Chaulya S K, Tewary B K and Dhar B B 1996 Restoration of a coal-mine overburden dump - A case study; Coal Int. 244 83-88.

Skinner F A 1971 Isolation of soil consortia in Isolations of Anaerobes (eds) Chapton D A and Board R L, Technical Series 5 57-80.

Tabatabai M A and Bremner J M 1969 Use of p-nitrophenyl phosphate for essay of soil phosphatase activity; Soil Biol. Bioche. 1 301-317.

Tiwary R K 2001 Environmental impact of coal mining on water regime and its management; Water, air and Soil Pollution 132 185-199.

Vance C P 2000 An extraction method for measuring soil microbial biomass C; Plant Physiol. 127 390-397.

Wong M H 2003 Ecological restoration of mine degraded soils, with emphasis on metal contaminated soils; Chemosphere 50 775-780. 